\title{
Plastik fantastisk: En analyse og diskussion af politikker for plastaffaldshåndtering
}

\author{
Af Kenneth Mølbjerg Jørgensen og Marita Svane *)
}

\begin{abstract}
Resumé
Med plast som case beskæftiger denne artikel sig med, hvordan vores økonomi kan transformeres til en bæredygtig økonomi. Casen handler om indsamling og genanvendelse af plastik og blev undersøgt som en del af projektet Ren Kystlinje. Det er artiklens hensigt at diskutere og problematisere de politikker for plastaffaldshåndtering, som er formuleret af EU og regeringen. Argumentet er, at disse politikker i vid udstrækning er baseret på ideer om Delt Værdi, som er en forholdsvis ny teori indenfor CSR-området, samt Cirkulær Økonomi (CØ). Der argumenteres for, at Delt Værdi og CØ indeholder en positiv fortælling, der imidlertid også har som funktion at legitimere en dominerende produktions- og forbrugskultur. Ved hjælp af interviews med aktører inden for genanvendelsesfeltet problematiseres, hvorvidt og i hvor stor udstrækning Delt Værdi og CØ kan løse problemerne vedrørende plastaffaldshåndtering og plastikforurening. Som et sidste element i artiklen diskuteres andre modeller til at håndtere plastaffaldsproblemerne.
\end{abstract}

\section{Emneord}

Plastaffaldshåndtering, bæredygtighed, ren kystlinje, Cirkulær Økonomi, Delt Værdi, Corporate Social Responsibility

\footnotetext{
*) Kenneth Mølbjerg Jørgensen er professor og ph.d. og Marita Svane er lektor og ph.d. Begge er tilknyttet Institut for Økonomi og Ledelse ved Aalborg Universitet. Kenneth er desuden gæsteprofessor ved University West i Trollhättan i Sverige.
} 


\section{A. Introduktion}

\section{Problemfelt}

Denne artikel diskuterer de bæredygtighedsstrategier og -politikker for plastaffaldshåndtering, som tages i anvendelse for at løse problemstillingen vedrørende plastikforurening. Særligt diskuteres plastaffaldshåndteringspolitikker ud fra to populære begreber, Corporate Social Responsibility (CSR) og Cirkulær Økonomi (CØ). Der argumenteres for, at de bæredygtighedspolitikker, som er formuleret af EU og den danske stat inden for plastområdet, baserer sig på ideerne om Delt Værdi, som er en forholdsvis ny teori indenfor CSR-området, samt CØ, som handler om affaldshåndtering og genanvendelse. Denne artikel undersøger betingelserne for, at Delt Værdi og CØ kan fungere inden for plastområdet ved at konfrontere de fortællinger, som er indlejret i bæredygtighedspolitikkerne, med fortællinger fra virksomheder inden for plastgenanvendelsesområdet. Med udgangspunkt i EU's plastikcirkulære, regeringens handlingsplan for plastområdet og interviews med aktører inden for plastgenanvendelsesindustrien påvises nogle problemer ved Delt Værdi og CØ. Dermed problematiseres, hvorvidt og i hvilket omfang Delt Værdi og CØ er og kan blive en del af selve løsninger på problemet. Specifikt peges på, at disse begreber også bruges til at legitimere en uholdbar produktions- og forbrugskultur.

Mere specifikt kan Delt Værdi og CØ anskues som en del af en større fortælling, som skal aflede opmærksomheden fra eksponentielt stigende affaldsmængder, som er en direkte effekt af en forbrugs- og smid-væk kultur. Der er efterhånden ved at opstå en bevidsthed om knappe ressourcer, og affald har fået stigende politisk opmærksomhed. Der gøres imidlertid ikke fundamentalt op med eksisterende økonomiske tankegange. I stedet gøres affald til en ressource, som private virksomheder kan skabe arbejdspladser, profit og økonomisk vækst ud fra. Ved at beskrive affaldsmængden som en ressource, dirigeres opmærksomheden væk fra politisk regulering og indgreb over mod de mange potentialer, som kan ligge i affald. Problemstillingen omkring affald skubbes derved også væk fra at være et problem, som vedrører private produktionsformer og forsyningskæder over mod at være et spørgsmål om affaldshåndtering. Det betyder, at plastaffald og plastforurening er et problem for det offentlige Danmark og ikke for private virksomheder.

Analyser af bæredygtighedsstrategier i forhold til plasthåndtering har generel relevans for refleksioner over, hvordan vi arbejder med bæredygtighedsproblematikker, da CØ og Delt Værdi generelt spiller en vigtig rolle i de politikker, der bliver formuleret. Desuden sætter plastaffald tingene på spidsen i vores økonomi. Mange af problemstillingerne ved den vestlige kulturs og de herskende økonomiske tankegange afspejles direkte i plastanvendelsen og i plastaffaldet. Der tænkes her særligt på to egenskaber ved plast. Plast er for det første et syntetisk produkt. For det andet er det kun langsomt nedbrydeligt. På den måde sættes der fokus på to centrale problemstillinger i den vestlige økonomi. Den ene vedrører selve ressourceanvendelsen. Plast 
produceres primært af olie, hvilket betyder, at det skabes ud fra råstoffer, som ikke umiddelbart kan regenerere sig selv. Da plast ikke er et organisk materiale, er det svært at komme af med plasten. Det ender som affald i industrien, husholdningerne og naturen. Det andet vedrører forbrug, hvor særligt plast i form af emballage og engangsplast har nogle af de korteste produktlivscyklusser overhovedet. Plast er således et af de reneste symboler på forbrug-og-smid-væk kulturen i den vestlige økonomi.

\section{Oversigt over artiklen}

Artiklen er struktureret på følgende måde. I det næste afsnit beskrives projektet, Ren Kystlinje, som artiklen er skrevet på baggrund af, og hvor vi også kort indikerer omfanget af plastforureningen. Dette følges op af en analyse af de strategier og politikker, som fra politisk hold bliver formuleret til at håndtere plastforureningen. Ved hjælp af interviews med udvalgte aktører fra plastgenanvendelsesindustrien diskuteres muligheder og begrænsninger ved de strategier, som formuleres fra politisk hold. I den sidste del af artiklen beskrives andre organiseringsmodeller til at håndtere plastaffaldsproblematikken.

\section{B. Ren Kystlinje og plastproblemet}

Projektet, Ren Kystlinje ("Ren Kustlinje-Symbioscentrum," 2018) blev skabt på grund af problemerne vedrørende plastaffald. Projektet løb fra 1. januar 2016 til 31. december 2018. Det var et samarbejde mellem en række forskellige kommunale aktører i Norge, Sverige og Danmark samt Skagen Uddannelsescenter, KIMO Danmark, Göteborg Universitet, Havforskningsinstituttet og Aalborg Universitet, Institut for Økonomi og Ledelse. Projektet havde følgende målsætninger:

- At udvikle fælles forskningsmetoder samt udføre og teste resultater på lokalt niveau

- At udvikle og teste nye innovative metoder og metoder for at reducere maritimt affald i Kattegat-Skagerrak regionen.

- At udvikle arbejdsformer og finansieringsmodeller for at håndtere maritimt affald.

- At implementere projektets resultater i den offentlige forvaltning og øge bevidstheden om problemet

Aalborg Universitet var en del af arbejdspakke 5, som handlede om behandling af indsamlet affald. En del af dette arbejde bestod i at indsamle data i form af interviews og samtaler med relevante aktører, deltagelse i arbejdsmøder, samt indsamling af relevante dokumenter og artikler vedrørende plastproblematikken. Rollen bestod i at kigge på potentielle forretningsmodeller i forhold til genanvendelse af havplast ud fra en ide om at vi skal bevæge os fra lineær økonomi til cirkulær økonomi. Arbejdet blev grebet an ved at kigge på indsamling og genanvendelse af plast generelt set, 
for derigennem at kunne sammenligne problemstillinger ved genanvendelse af plast fra landjorden med de problemstillinger, som knytter sig til det plastaffald, som kommer ind fra havet. Her er der også opnået indsigt i de forskellige plasttyper og egenskaber ved plast, som der skal tages hensyn til, når vi taler om genanvendelse af plast.

En af problemerne vedrørende genanvendelse af plast består i, at der findes mange forskellige typer af plast. Fælles for alle typer er, at de er formbare og kan støbes. Plast kan være hård eller blød. Nogle smelter let, mens andre kan tåle høj varme-eksempelvis Teflon. Bakelit var det første helt kunstige plastmateriale opkaldt efter den belgiske kemiker Bakelit. I 1920'erne begyndte man at lave plast af råolie. Det er den plast, vi kender i dag. Plast har erstattet materialer mange steder, for eksempel som rør og tagrender. En fordel ved plast er, at man let kan få det til at ligne andre materialer, for eksempel metal, glas og træ. Plast bruges også tit sammen med andre materialer, for eksempel metal, glas, pap og papir.

Plast er således ikke blot én ting med bestemte egenskaber. En del af problemstillingerne vedrørende håndteringen og genanvendelse af plast knytter sig præcist til, hvilke typer af plast, som vi taler om. I dag er plast en naturlig del at vores liv. Det har så stor betydning, at vi har svært ved at forestille os et liv uden plast. I den henseende glemmer vi ofte, at plast er et forholdsvis nyt produkt. Produktionen af plast tog først for alvor fart i 1960'erne. Da plast i dag er alle vegne, og fordi der er mange forskellige typer af plast, er tallene omkring plastforurening usikre. Nedenstående tal skal derfor læses med stor forsigtighed. Vi har ikke undersøgt eller diskuteret validiteten af disse tal nærmere men bruger dem alene til at give en fornemmelse af omfanget plastforeningen.

Ifølge kilder bliver der produceret omkring 9,5 tons plast hvert sekund, og hvert år ender 10 millioner tons plastaffald i havene ("Out to Sea - an ocean of plastic," 2019). Den første affalds-ø i havet blev opdaget i 1999. I dag har der samlet sig 8 større plastaffalds-øer i havene. Den næste historie er stærkt foruroligende: "I 2050 vil der være ligeså meget plast i havene, som der vil være fisk" (Jyllands-Posten, 2018). Plastikforureningen udgør en markant trussel, da plast forurener havmiljøet og hvert år dræber millioner af fugle, fisk og havdyr. Dertil kommer, at mikroplast ophober sig i fødekæden. Der er ingen, der kender effekten af denne ophobning på hverken dyr eller mennesker. Faren er både direkte og indirekte i og med, at plastikforureningen efterhånden er så massiv, at den griber ind i naturens cyklusser med potentielt uoverskuelige konsekvenser til følge.

Ren Kystlinje blev dannet, fordi alle 28 involverede kystkommuner oplevede stigende problemer med plastaffald. Kommunernes fokus var at løse en konkret problemstilling: Hvordan kan vi effektivt håndtere de stigende mængder af plastaffald, der driver ind fra havene? AAU har haft en anden mindre defineret position og har haft til opgave at anskue plastaffald ud fra et bredere erhvervsøkonomisk og samfundsmæssigt perspektiv. Vi har gennemført en undersøgelse af 
betingelserne for at kunne genanvende plast, hvor vi talte med aktører fra plastgenanvendelsesindustrien. Vi talte med i alt 8 aktører inden for området, hvoraf fem var repræsentanter for virksomheder, mens de sidste tre repræsentanter for interesseorganisationer. Vi har brugt fire af interviewene fra virksomhederne. Den sidste vurderede vi som mindre relevant, da denne virksomhed var ny og ikke havde etableret sig endnu.

Metoden, vi anvendte, var kvalitative interviews af ca. en times varighed. Vores forberedelse bestod i en kritisk læsning af artikler og dokumenter for, at vi kunne få en fornemmelse af de dominerende diskussioner og løsningsscenarier, som blev stillet op vedrørende plastforurening. Vi var herefter interesserede i at få et billede af virksomhedernes forretningsmodel og de betingelser, som er knyttet til genanvendelse af plast. På den måde, kunne vi sammenligne de fortællinger, som er indlejret i diskussioner og løsningsscenarier vedrørende plastforurening, med virksomhedernes egne fortællinger. Vi var interesserede $\mathrm{i}$ at få en dybere forståelse af problemstillinger vedrørende CØ inden for plastindustrien snarere end at teste teori. De fire virksomheder har alle fået tilsendt rapporten med henblik på kommentering af de dele, som vedrørte dem.

I projektbeskrivelsen var plastgenanvendelse en del af de mulige løsninger, som skulle undersøges. I det følgende afsnit vil vi først analysere de politiske initiativer, som sættes i værk for at løse plastproblematikken. Her vil vi benytte dokumenter fra EU som udgangspunkt. Vi vil diskutere disse ud fra CSR med særligt fokus på Delt Værdi og CØ. Dernæst konfronteres disse med de fortællinger, som vi har indhentet fra Ren Kystlinje. Dette gøres med henblik på at kortlægge betingelserne for, at CØ kan fungere inden for plastgenanvendelsesområdet. Vi vender dernæst øjnene mod den danske plasthandlingsplan og diskuterer denne i lyset af erfaringerne fra Ren Kystlinje projektet. Endelig skitseres mulige andre organiseringsmodeller til plastaffaldshåndtering.

\section{Plastaffald som en kilde til Delt værdi}

Corporate social responsibility (CSR) har indenfor organisations- og ledelseslitteraturen har været en dominerende teoretisk tilgang til at forstå, hvordan virksomhedsstrategi og samfundsmæssigt ansvar kan kombineres. CSR er en ramme, som fortæller om virksomheders ansvar i forhold til miljø, klima, planeten, menneskerettigheder, menneskers leve- og arbejdsvilkår samt i det hele taget, hvordan virksomheden bør placere sig i forhold til samfund og omverden. CSR består i dag af flere konkurrerende perspektiver, som hver især afspejler forskellige opfattelser af, hvad en virksomhed er (Vallentin, 2011).

Et klassisk "shareholder" perspektiv betoner, at virksomhedens primære ansvar er rettet mod ejerkredsen, aktionærerne og deres indtjening. Et "stakeholder" perspektiv betoner derimod, at 
virksomheden som "institution" i samfundet er en del af samfundet og derfor må enten tilpasse sig samfundets krav eller må tage et ansvar for samfundet. Dette ansvar forøges i takt med virksomhedens størrelse. Nedenfor vises en kort oversigt over CSR-tilgange, hvor de er delt op ud fra, hvorvidt det er et shareholder eller stakeholderperspektiv, og hvorvidt der er tale om passiv tilpasning eller aktiv stillingtagen.

\begin{tabular}{|l|l|l|}
\hline & $\begin{array}{l}\text { Shareholder-perspektiv } \\
\text { (neoklassisk perspektiv) }\end{array}$ & $\begin{array}{l}\text { Stakeholder-perspektiv } \\
\text { (Institutionelt perspektiv) }\end{array}$ \\
\hline $\begin{array}{l}\text { Passiv tilpasning til samfundet krav } \\
\text { og forventninger. }\end{array}$ & $\begin{array}{l}\text { CSR er at maksimere } \\
\text { profitten. Regulering skal i } \\
\text { højst muligt omfang undgås. }\end{array}$ & $\begin{array}{l}\text { CSR er et spørgsmål om pragmatisk } \\
\text { tilpasning til love, regler, } \\
\text { samfundsdynamikker (corporate } \\
\text { social responsiveness) }\end{array}$ \\
\hline Aktiv stillingtagen. & $\begin{array}{l}\text { CSR er et spørgsmål om at } \\
\text { skabe Delt Værdi. Samfund- } \\
\text { og miljømæssige problemer } \\
\text { er strategiske muligheder } \\
\text { for virksomheder. }\end{array}$ & $\begin{array}{l}\text { CSR er et spørgsmål om at } \\
\text { virksomheder skal engagere sig i } \\
\text { samfundsmæssige spørgsmål. }\end{array}$ \\
\hline
\end{tabular}

Tabel 1: CSR-perspektiver (egen tilvirkning)

I de senere år har et perspektiv, som befinder sig indenfor shareholder-tankegangen vundet indpas, nemlig "Shared Value", eller Delt Værdi (Porter \& Kramer, 2011). Denne tilgang er særligt interessant i forhold til den politiske fortælling om plastaffald. Kort sagt går Delt Værdi ud på, at organisationers strategiske tænkning og miljøspørgsmål kan kombineres succesfuldt. Derfor kendes Delt Værdi også som strategisk CSR. Plastaffald kan ud fra dette perspektiv betragtes som en strategisk mulighed, som kræver offensiv strategisk tænkning. På denne måde anskue et samfundsmæssigt problem som en kilde til vækst, arbejdspladser og profit (Vallentin, 2011).

Delt Værdi er således en glad fortælling. Ifølge Garriga \& Melé (2004) deler den imidlertid nogle basale antagelser omkring, hvad en virksomhed er, med en af dens kendte forgængere indenfor CSRlitteraturen, nemlig Chicagoøkonomen Milton Friedman. I en kronik i New York Times udtalte han, at en virksomheds sociale ansvar simpelthen er at forøge dens profit (Friedman, 1970). Socialt ansvar er ifølge Milton Friedman ikke noget, som er en virksomheds ansvar. Det er kunderne, der via køb eller fravalg af produkter eller serviceydelser, bestemmer, hvorvidt en virksomhed skal være socialt ansvarlig eller ej. Ellers bør virksomheden blot følge lovgivningen.

Delt Værdi deler ikke Friedman's manglende etiske syn på CSR, men kan også fortolkes som om, at den har profitten i højsædet ligesom at den kan kritiseres for at anskue virksomheden for snævert 
ud fra et shareholder perspektiv. På den måde er der nogle begrænsninger ved Delt Værdi. Freeman, Wicks og Parmar (2004) fremhæver, at vi bør søge arbejde ud fra et bredere stakeholder perspektiv, som ophæver modsætningen mellem på den ene side etik og på den anden side bundlinjen. Her er profit snarere resultatet end det, der driver værdiskabelsen.

De nævner også, at ideologierne bag shareholder perspektiver indeholder et bestemt politisk formål, nemlig at den private virksomheds frihed skal bevares i stedet for, at der kommer for meget politisk regulering. Delt Værdi kan i forlængelse heraf ses som både en glad fortælling og en populær fortælling, fordi den postulerer, at værdi kan skabes ved at tilgodese flere interessenters behov og hensyn i værdikæden, samtidig med at der løses miljømæssige problemer og dermed problemer vedrørende eksempelvis plastforurening. Men Delt Værdi bør også anskues kritisk i forhold til de interesser, som denne fortælling tjener.

I Delt Værdi bliver plastaffald til en ressource og mulighed for nye forretnings- og markedsmuligheder, der derved forener etiske og forretningsmæssige hensyn. Delt Værdi anskues ofte i en sammenhæng med Corporate Social Innovation (CSI), som kobler miljø- og samfundsmæssige problemer med entreprenørskab. Løsningen af miljøproblemer er altså en markedsmulighed og indeholder et vækstpotentiale for nystartede virksomheder såvel som for de etablerede. Tankegangen er attraktiv, fordi den fokuserer på mulighederne for at kommercialisere etiske problemer. I næste afsnit skal vi kigge på, hvordan denne glade fortælling dominerer EU's plastikstrategi.

\section{Strategier for at genanvende plast}

I januar 2018 udkom et nyt plastikcirkulære fra EU. Vi mener, at overskriften i pressemeddelelsen på mange måder afspejler tankegangen bag Delt Værdi. Det er fokus på virksomheders og industriens forretningsmuligheder i at genanvende mere. Plastaffaldsproblematikken skal således afhjælpes på en måde, således at der skabes vækst og jobmuligheder ved at lave systemer for plastgenanvendelse. Overskriften lyder således: "Plastic waste: a European Strategy to protect the planet, defend our citizens and empower our industries". Det er karakteristisk, at beskyttelsen af miljøet bliver præsenteret som en stork business case.

It will protect the environment from plastic pollution whilst fostering growth and innovation, turning a challenge into a positive agenda for the future of Europe. There is a strong business case for transforming the way products are designed produced, used, and recycled in the EU and by taking lead in this transition, we will create new investment opportunities and jobs. Under the new plans, all plastic packaging on the EU market will be recyclable 
by 2030, the consumption of single-use plastic will be reduced and the intentional use of microplastic will be restricted"

(European Commission, 2018, vores fremhævning)

Selvom planerne også indeholder regulering, er det den positive fortælling om vækst og jobs, som er i fokus. Der bliver også stillet en række krav, og der defineres nogle rammebetingelser og incitamenter, som skal få private virksomheder til at ville løfte opgaven og skabe en forretning på plastgenanvendelse. Men det er den positive fortælling, som dominerer. Plastaffald anerkendes i dokumentet som værende meget stort. Følgende nøgletal giver nogle indikationer på problemstillingens omfang (European Commission, 2018a).

- 49 millioner tons plastik efterspørges hvert år i EU. Af disse efterspørges $40 \%$ indenfor forpakning, 20\% indenfor byggeri og konstruktion, 9\% indenfor automobilindustrien og 6 indenfor elektronikindustrien.

- I EU er der ansat 1,5 millioner mennesker indenfor plastikindustrien, som genererer en omsætning på 340 milliarder euro.

- Det konkluderes, at genbrug og genanvendelse af plastikprodukter stadig er meget lavt i sammenligning med papir, metal og glas.

- Plastaffald omfatter ca. 26 millioner tons i 2015. Disse fordeles således: Forpakninger (59\%), husholdningsaffald som ikke er forpakninger (4\%), Byggeri og nedrivning (5\%), Elartikler og elektronik (8\%), automobilindustri (5\%), landbrug (5\%) og andre (14\%).

- Der er mindre end $\mathbf{3 0 \%}$ af dette affald, der indsamles med henblik på genbrug.

- Deponering og forbrænding er stadig højt, hhv. 31\% og 39\%. Mens deponeringen er faldende er forbrændingsprocenten til gengæld stigende. Ifølge vurderinger går 95\% af værdien af plastforpakninger tabt efter ganske kort tid.

- Efterspørgslen efter genanvendt plast udgør kun 6\% af den samlede efterspørgsel i Europa.

- Plastikproduktionen og plastikafbrændingen forøger CO2 udledningen med 400 millioner tons om året.

- Globalt set vurderes det, at mellem 5 og 13 millioner tons plastaffald (mellem 1,5-4\%) af produktionen ender i havet hvert år. I EU ender mellem 150.000-500.000 tons plastaffald hvert år.

Det konkluderes altså, at genanvendelse af plast ikke har været en tilstrækkelig stærk business case hverken i Europa eller globalt set. Genbrug af plast er meget lavt sammenlignet med andre sektorer. Dog går visionen imod en bæredygtig cirkulær økonomi ifølge EU ikke via restriktioner eller forbud, men via at skabe stærke business cases. Det er en strategi, som også fremhæves i den Danske Plastikhandlingsplan, som udkom senere på året som en udmøntning af EU's plastcirkulære (Miljø- 
og Fødevareministeriet, 2018). Det er således entreprenørerne, der skal løse problemet. Der tales ikke om markant regulering, selvom regulering nok hele tiden lurer i baggrunden som en latent trussel. Miljøspørgsmål underordnes således erhvervsmæssige spørgsmål. Dette afspejles direkte i den økonomiske tankegang, som ligger til grund for EU's plaststrategi og regeringens handlingsplan, som er CØ.

Et af kernepunkterne i CØ er genanvendelse af affald for derigennem at lægge bånd på, hvad der bliver smidt væk, men også de ressourcer, vi forbruger. Derfor har regeringens plasthandlingsplan den flotte titel "Plastik uden spild" (Miljø- og Fødevareministeriet, 2018). Tankegangen er, at ved at genanvende vil der blive mindre affald, og vi vil bruge færre ressourcer fra jorden. Samtidig skal vi ikke være blinde for, at cirkulær økonomi er endnu en glad fortælling, som fortæller, at vi via genanvendelse kan opretholde den nuværende produktions- og forbrugsøkonomi intakt. Tankerne om cirkulær økonomi fremgår tydeligt af regeringens handlingsplan, som følger af visionerne for en bæredygtig plastøkonomi i EU. EU's visioner er følgende (European Commission, 2018a):

- Plastik og produkter, som indeholder plastik, designes så de har en længere levetid og en høj grad af genbrug af og genanvendelighed. I 2030 skal alle plastforpakninger på EUmarkedet været genbrugeligt eller genanvendeligt på en omkostningseffektiv facon.

- Forandringer i produktion og design skal gøre det muligt at få højere genanvendelsesrater for all nøgleapplikationer. I 2030 skal mere end halvdelen af det plastaffald, som genereres i Europa, genanvendes.

- EU's genanvendelseskapacitet skal være signifikant udvidet og moderniseret. I 2030 skal den være firedoblet i forhold til 2015, hvilket skal lede til 200.000 nye jobs.

- Takket være forbedrede sorteringsmetoder og investeringer i innovation, færdigheder og kapacitetsopbygning, er eksporten af dårligt sorteret plastaffald blevet faset ud. Genanvendt plastik anses som en attraktiv ressource for industrier både i EU og udenfor.

- Plastikværdikæden er langt mere integreret og den kemiske industri arbejder sammen med plastgenanvendelsesvirksomheder i forhold til at finde værdifulde anvendelser af deres produkter. Substanser, som forhindrer genbrug og genanvendelse, er faset ud.

- Markedet for genanvendt og innovativ plast er succesfuldt etableret med klare vækstperspektiver og flere og flere produkter inkorporerer genanvendt indhold. Efterspørgslen efter genanvendt plast er firedoblet, således at der er et stabilt indtægtsgrundlag og jobsikkerhed i sektoren.

- Mere plastgenanvendelse hjælper med at gøre EU uafhængige af fossile brændstoffer and reducere $\mathrm{CO} 2$ udledningen. 
Dette lyder som en flot og ambitiøs strategi, hvor der bliver lavet et effektivt kompromis mellem miljøspørgsmål og økonomiske hensyn. Men det er alligevel et kompromis, hvor miljøet risikerer at blive tabt. Problemet er, som det også anføres, at plastik er billigt og nemt at producere og er nyttigt i mange forskellige sammenhænge. Det er en billig og effektiv teknologi, som på mange måder afspejler, hvor fantastisk dygtige og effektive, vi er blevet. Når vi skal vurdere ovenstående tal, skal vi ikke sammenligne det ud fra en forestilling om, at produktionen af plastik er nogenlunde stabil. Det er den langt fra. Regeringens egen handlingsplan fortæller faktisk selv, hvor meget plastikproduktionen egentlig er steget fra 1,7 mio. tons i 1950 til 311 mio. tons i 2014. Det estimeres her, at produktionen vil nå hele 1,2 mia. tons i 2050. Andre tal fortæller, at omtrent halvdelen af den plastik, der er produceret i alt på verdensplan, er produceret i perioden fra 2004-2017 (DAKOFA, 2017). Når vi taler om, at halvdelen af alt plastikaffald skal kunne genanvendes, og at kapaciteten i forhold til genanvendelse skal være firedoblet, skal dette vurderes i forhold til den store og vedvarende acceleration i plastikproduktion og forbrug. Selv om EU's plaststrategi lykkes, kan vi altså alligevel ende med at stå med plastaffaldsproblemer, der er endnu større, end de er i dag.

\section{E. Betingelser for cirkulær økonomi: Erfaringer fra Ren Kystlinje}

EU's plastikcirkulære fortæller sammen med den danske plastikhandlingsplan, som vi kigger på senere, om problemstillingerne med plastforurening. Der appelleres til entreprenørerne og innovationslysten, og hvor det eksplicit påpeges fra både EU og regeringen, at man ikke tror på regulering. Simpel Omtanke sammen med $C \varnothing$ fremhæves som løsningsmulighederne. Plastikaffald præsenteres som en oplagt case for Delt Værdi for entreprenører. Da CØ og Delt Værdi er populære begreber, valgte vi at tale med 5 aktører fra fem virksomheder, som arbejder med plastikgenanvendelse, om, hvordan deres forretningsmodeller er opbygget.

Vi talte med aktørerne om betingelserne for at kunne genanvende plastik, og dermed talte vi om betingelserne for at kunne lave en økonomisk bæredygtig forretningsmodel af den type, som EU og den danske regering efterspørger flere af. I forhold til genstandsfeltet, plastik, var konklusionerne rimeligt entydige i forhold til den problemstilling, som handler om at lave plastaffald om til nye en råvare og recirkulere denne plast i produktionen af nye produkter. Der er andre typer af plastgenanvendelse, hvor eksempelvis plastaffald bliver genbrugt i tøj, og havplast specifikt forsøges anvendt som brandværdi i produktionen af eksempelvis, sko, sportstøj eller kunst. Sådanne typer af forretningsmodeller er interessante, men vedrører kun en meget lille del af det samlede plastaffald. I forhold til at lave plastaffald om til en ny råvare, til såkaldt granulat, var der bred enighed om, at nogle forudsætninger for plastgenanvendelse skal være opfyldt, for at plastgenanvendelse er økonomisk bæredygtigt. Disse forudsætninger kan sammenfattes i fem nøgleord: 
- Mængder

- Renhed

- Kvalitet

- Komposition

- Sortering

Det første spørgsmål er således, hvorvidt virksomhederne kan få plasten tilsendt i tilstrækkeligt store moengder? Dette relaterer sig til eksempelvis transportomkostninger. For virksomhederne er det centralt, at leverancesystemet er økonomisk effektivt. En virksomhed inden for plastgenanvendelse havde gjort sig den erfaring, at den i sin opstart havde for mange opsamlingspunkter. Derfor var den begyndt at reducere i disse. En problemstilling, som blev nævnt i denne sammenhæng var, at affaldshåndteringen i Danmark er et kommunalt anliggende, hvilket betyder, at der er forskellige principper for affaldshåndtering, og at det derfor kan være svært at levere brugbar plast i tilstrækkelige mængder. Den kommunale affaldshåndtering er også et problem vedrørende sortering, som vi vender tilbage til nedenunder.

Det andet spørgsmål vedrører plastens renhed. Dette refererer til, hvorvidt og hvilket omfang plasten er rengjort, før den sendes til genanvendelse. I forhold til eksempelvis begrebet husholdningsplast handler dette om, hvorvidt eksempelvis shampoo eller mayonnaiseflasker er rengjorte, så de kan håndteres i affaldssorteringssystemerne, så fabrikshallerne ikke bliver fyldt op med skum og sæbebobler, og anlæggene ikke går i stykker.

Det tredje spørgsmål vedrører plastens kvalitet. Inden for havplast findes eksempelvis begrebet spøgelsesnet, som refererer til efterladte fiskenet på havbunden. Der var det et problem for en af virksomhederne, at en tur i havet gjorde noget ved kvaliteten af plasten, så det i mange tilfælde ikke kunne genbruges. Dette siger noget om, at der er visse begrænsninger i troen på, at plast fra havet blot kan samles op og genbruges. Solen og havet i kombination gør noget ved plastens kvalitet.

Det fjerde spørgsmål vedrører plastens komposition. Hvad består plasten af, og hvordan er den sammenblandet. En respondent beskriver problemstillingen ud fra en flaske kakaomælk.

Flasken er PET (Polyetylentereftalat), teksten omkring er folie, og låget er PP (Polypropylen)

(Interview materiale) 
Han beskriver det som et producentproblem. Konsekvenserne er, at man ikke altid ved, hvilke typer plast, vi har med at gøre, og at sammenblandingen af plasttyper i sig selv gør sorteringen mere omkostningstung.

Dette leder frem til det sidste spørgsmål, som er sorteringen. Hvor godt er plasten er sorteret? Dette er forbundet med omkostninger ved at adskille genanvendeligt plast fra u-genanvendeligt plast, og ved problemer, som handler, at virksomhederne skal vide, hvilke plasttyper, som de har med at gøre. De centrale forudsætninger i en plastgenanvendelse, når vi taler om at lave plastaffald om til en ny råvare, er knyttet til disse forudsætninger. En af aktørerne var meget klar i sin beskrivelse af denne problemstilling.

[...] når vi taler om A (andre virksomheder) og os, så taler vi jo om A- og B-plastmarkedet. Aplastmarkedet er erhverv, hvor du har en homogen proces og en homogen indflyvning og et homogent restprodukt. Vent til du ser virkeligheden hos os... Nu møder du B-plast. Det er en meget fragmenteret plast, og det er sammensat plast.

(Interviewmateriale)

Med disse eksempler har vi bevæget os ind på nogle af forudsætningerne for CØ og Delt Værdi inden for plastområdet. En af præmisserne for at CØ fungerer er ganske vist affaldshåndtering og en effektiv sortering. Men en effektiv affaldshåndtering og sortering afhænger også eksempelvis af design af plast og produktion af plast. Derfor kom plastindustrien også med en artikel, hvor det fremgår, at "Vi vil designe plastemballage til genbrug og genanvendelse" (Plastindustrien, 2018). Rene plastmaterialer frem for sammensatte materialer, prioriteringer af bestemte plasttyper, samt at emballagen skal være lettere at rengøre, er centrale elementer heri.

Andre initiativer, som går i denne retning, er producentansvar samt en ensretning i den måde, som kommunerne indsamler husholdningsplast på (Plastindustrien, 2018). Formålene i disse initiativer er at gøre det lettere at sortere plastaffald ved at skabe en større grad af homogenitet. Der er nogle centrale betingelser, som er vigtige at forstå i forhold til, hvornår plastgenanvendelse er en god forretning, og hvornår der er problemer. Når aktøren ovenfor taler om et A-marked og et B-marked, refererer han reelt set til de plastgenanvendelsesvirksomheder, som har bygget en forretningsmodel op omkring at lave granulat fra industriplastaffald. En af aktørerne fra en af disse virksomheder har en effektiv forretningsmodel, da de formår at lave $97 \%$ af plastaffaldet om til ny granulat.

Ja, det er den filosofi, vi har hele tiden. Også når vi går ind i projekter med plast fra havet [...] Vi rører kun ved det, som vi ved kan laves om til et produkt, som kan genanvendes igen. Det virker sådan. Vi er lidt kræsne. Vi anses for at være kræsne, fordi folk vil jo gerne af med plast. Vi vil have, at de skal sortere i det først. Vi vil ikke 
være en sorteringscentral, fordi så bliver det sådan, at det vil komme fra et eller andet. De vil holde i kø [...], hvis vi åbnede for det hele [...] Vi vil kun kunne bruge 50\% af det der kom, og det vil vi ikke.

(Interviewmateriale)

Han fortæller samtidig, at langt hovedparten af plasten, indtil tidspunktet for interviewet, var kommet fra industrien.

Det er klart, at der får vi det fra den del af industrien, der vil sortere. Så betaler vi også for det [...] Vi kan faktisk godt give en god pris for plasten, hvis den er sorteret ordentligt.

(Interviewmateriale)

Han fortæller dog også, at de er på vej ned af rangstigen i forhold til at tage den mere udfordrende plast, men hvor det påpeges, at det skal gøres i små skridt, så teknologien kan følge med. Han siger her lidt om hovedtallene for Danmark i forhold til plastgenanvendelse. Danmark er pænt med i forhold til genanvendelse af industriplastaffald. Til gengæld siger han, at Danmark er dårlige til at genanvende husholdningsplastaffald.

Hvis du kigger overordnet på det, så brænder vi (Danmark) 200 tusind tons af, eksporterer 100.000 tons, og så genanvender vi 50.000 tons.

(Interviewmateriale)

Han påpeger igen kildesortering som væsentlig her. Så kommer vi til havplasten, som han simpelthen kalder det rene "ondskab".

Plast fra havet. Det er ondskab. Grundlæggende så hører plast jo ikke til i havet, det er svineri. Det skal vi undgå. Så kan man sige, de fraktioner, man samler op ud fra kysten, er en udfordring, der ikke egner sig til genanvendelse. Jo, måske kunne du tage $20 \%$ af det, hvis du laver en sortering [...] Så de sidste $80 \%$ vil blive brændt af eller udnyttet på anden måde [...] Men plast fra havet er udfordrende. Sortering kan redde noget af det, men grundlæggende er der så mange mærkelige ting i det at [...]

(Interviewmateriale)

Denne forståelse af havplast støttes af udsagn fra en anden aktør: 
Det er egentlig materialet, der er vigtigt for at kunne genanvende. Det, der bliver indsamlet fra havet, er et mix af alt muligt. Det ville vi usorteret ikke kunne genanvende [...] Vi kræver fragment størrelser, der er ensartede, vi kræver enshed.

(Interviewmateriale)

Denne aktør udtalte, at der var en række projekter, som havde vist, at man kan godt kan genanvende husholdningsplast (husholdningsplast). Det er bare vanskeligt, fordi der findes alt for mange forskellige måder at sortere på i Danmark, da affaldshåndtering er et decentralt anliggende. Den virksomhed, denne aktør kommer fra, har en cirkulær forretningsmodel, hvor de plasttyper, som de laver, kan tages tilbage, smeltes om og laves til nye plastprodukter. Virksomheden lægger vægt på, at produktet skal kunne genbruges igen, når de producerer produkter. De har faste aftaler med kunderne om, at det primært er industriplast, der genanvendes. Han har mange andre interessante betragtninger om eksempelvis fordelene ved det gamle pantsystem for glasflasker, som blev genbrugt mange gange, mens plastikflasker bliver genbrugt til andre produkter uden at der er tale om CØ.

Sammenfattende kan der skelnes mellem tre overordnede plastaffaldsbegreber. Der er industriplast, som genbruges, og som kan genbruges i stort omfang. Der er få aktører involveret og et mindre kredsløb, der skal kontrolleres. Så er der husholdningsplast. Der er mange forskellige aktører, som er involveret. Plasten kommer potentielt mange steder fra. Det er meget mere svært at kontrollere. Et nyt affaldscirkulære vil gøre det muligt at genanvende mere. Generelt er der mange flere aktører, som skal samarbejde, når det gælder husholdningsplast: renovationsselskaber, virksomheder, offentlige organisationer og borgere. Så er der havplast. Det er umuligt at kontrollere. Det er spredt over store geografiske afstande. Det er sammenviklet med alt muligt andet, og derfor er det meget svært at genbruge.

Husholdningsplasten er noget, som man fra politisk hold er begyndt at fokusere mere på. I forhold til de opgørelsesmetoder, som EU anvender, er genanvendelsen af husholdningsplast meget lavt i Danmark, ca. 18\% (Regeringen, 2018). Målsætningen er, at dette tal skal op på 50\% i 2030 og her er nogle af indsatsområderne knyttet til en større ensartet sortering, mere ens standarder og et tættere samarbejde for at tilvejebringe større muligheder for genanvendelse. Casene har vist, at design, kontrol af materialer, kontrol af kredsløb, færre opsamlingssteder og et tættere samarbejde mellem aktørerne i hele værdikæden er en forudsætning for mere genanvendelse. 


\section{F. Regeringens plastikhandlingsplan}

Delt Værdi og CØ spiller som sagt en meget afgørende rolle for de politiske initiativer, som eksisterer inden for området. Vi har før kigget på EU's plastcirkulære. I slutningen af 2018 kom den danske plastikhandlingsplan, som ligger i forlængelse af plastcirkulæret. I forhold til omfanget af plastforureningen og de trusler, som vi nævnte tidligere, virker plastikhandlingsplanen lidt uambitiøs. Den ligger sig i forlængelse af ideerne om Delt værdi og den tilknyttede idé om, at det er entreprenører, som skal løse problemstillingen igennem nye forretningsmodeller og samarbejdsflader mellem aktører. Handlingsplanen gør det klart, at den daværende regering ikke troede på regulering, men i stedet på frivillighed og omtanke. Der er tillige kun afsat ca. 50 millioner til planen, som ellers omfatter hele 27 forskellige initiativer.

\begin{tabular}{|c|c|c|c|c|}
\hline $\begin{array}{l}\text { 1. Nationalt } \\
\text { plastikcenter }\end{array}$ & $\begin{array}{l}\text { 7. Udvidet } \\
\text { producentansvar } \\
\text { for emballage }\end{array}$ & $\begin{array}{l}\text { 13. Undersøgelse } \\
\text { af spøgelsesnet i } \\
\text { danske farvande } \\
\text { og metoder til } \\
\text { oprensning }\end{array}$ & $\begin{array}{l}\text { 18. Analyse af } \\
\text { emballageafgifte } \\
n \text { på } \\
\text { engangsservice } \\
\text { for at reducere } \\
\text { plastikforbrug }\end{array}$ & $\begin{array}{l}23 . \\
\text { Vidensopbygning } \\
\text { om fordele og } \\
\text { ulemper ved } \\
\text { biobaseret og } \\
\text { bionedbrydeligt } \\
\text { plastik. }\end{array}$ \\
\hline $\begin{array}{l}\text { 2. Analyse af } \\
\text { Danmarks } \\
\text { plastikforbrug og } \\
\text { håndtering }\end{array}$ & $\begin{array}{l}\text { 8. Standarder for } \\
\text { sortering og } \\
\text { indsamling af } \\
\text { plastikaffald }\end{array}$ & $\begin{array}{l}\text { 14. Forbud mod } \\
\text { uddeling af gratis } \\
\text { bæreposer med } \\
\text { hank }\end{array}$ & $\begin{array}{l}\text { 19. Forbud mod } \\
\text { tilsætning af } \\
\text { mikroplast i } \\
\text { kosmetiske } \\
\text { produkter }\end{array}$ & $\begin{array}{l}\text { 24. Kortlægning af } \\
\text { PVC-produkter på } \\
\text { det danske marked } \\
\text { og } \\
\text { substitutionsmuligh } \\
\text { eder }\end{array}$ \\
\hline $\begin{array}{l}\text { 3. Kortlægning af } \\
\text { udviklings- og } \\
\text { forretningspotentiale } \\
\text { r for danske } \\
\text { virksomheder }\end{array}$ & $\begin{array}{l}\text { 9. Danmark støtter } \\
\text { EU-kommissionens } \\
\text { engangsplastikdire } \\
\text { ktiv }\end{array}$ & $\begin{array}{l}\text { 15. Forbud mod } \\
\text { tynde } \\
\text { plastikbæreposer } \\
\text { med håndtag }\end{array}$ & $\begin{array}{l}\text { 20. Nationalt } \\
\text { forsknings og } \\
\text { innovationsnetv } \\
\text { ærk om } \\
\text { mikroplast }\end{array}$ & $\begin{array}{l}\text { 25. Fælles } \\
\text { europæiske krav til } \\
\text { design for } \\
\text { genanvendelse }\end{array}$ \\
\hline $\begin{array}{l}\text { 4. Prioritering af } \\
\text { forsknings- og } \\
\text { teknologiudviklingsm } \\
\text { idler }\end{array}$ & $\begin{array}{l}\text { 10. National } \\
\text { informationskamp } \\
\text { agne for at } \\
\text { reducere affald i } \\
\text { naturen }\end{array}$ & $\begin{array}{l}\text { 16. Danskernes } \\
\text { bæreposeforbrug } \\
\text { skal halveres } \\
\text { inden } 2023\end{array}$ & $\begin{array}{l}21 . \\
\text { Vidensopbygning } \\
\text { om mikroplast i } \\
\text { spildevandsslam }\end{array}$ & $\begin{array}{l}\text { 26. Opprioritering } \\
\text { af Danmarks } \\
\text { internationale } \\
\text { engagement. }\end{array}$ \\
\hline $\begin{array}{l}\text { 5. Sektorsamarbejder } \\
\text { indenfor for } \\
\text { eksempel landbrug, } \\
\text { byggeri, restauration } \\
\text { og detailbranchen }\end{array}$ & $\begin{array}{l}\text { 11. Pulje for lokale } \\
\text { initiativer til } \\
\text { rengøring af de } \\
\text { danske strande for } \\
\text { plastik }\end{array}$ & $\begin{array}{l}\text { 17. Udvikling af } \\
\text { krav om reduktion } \\
\text { af } \\
\text { engangsplastikfor } \\
\text { brug ved større } \\
\text { arrangementer }\end{array}$ & $\begin{array}{l}22 . \\
\text { Vidensopbygning } \\
\text { om } \\
\text { mikroplastudled } \\
\text { ning fra } \\
\text { kunstgræsbaner }\end{array}$ & $\begin{array}{l}\text { 27. Styrket indsats i } \\
\text { de nære } \\
\text { havområder. }\end{array}$ \\
\hline
\end{tabular}




\begin{tabular}{|l|l|l|l|l|}
\hline & & $\begin{array}{l}\text { og mulige } \\
\text { alternativer }\end{array}$ & \\
\hline $\begin{array}{l}\text { 6. Pant- og } \\
\text { retursystemet }\end{array}$ & $\begin{array}{l}\text { 12. Forbud mod } \\
\text { ikke-nedbrydelige }\end{array}$ & & & \\
flasker til juice og & haglskåle. & & & \\
saft fra 1. januar & & & & \\
2020 & & & & \\
\hline
\end{tabular}

Tabel 2: 27 initiativer i plastikhandlingsplanen (Miljø- og Fødevareministeriet, 2018)

Elleve af initiativerne $(1,2,3,4,13,18,20,21,22,23,24)$ handler om yderligere forskning og opbygning af viden. To af initiativerne $(10,11)$ handler om øget information. Et af initiativer $(5)$ handler om sektorsamarbejder. Otte af initiativerne $(9,12,14,15,16,17,19,25)$ handler om forbud mod anvendelse af nogle former for plast inden for specifikke områder og indførsler af standarder og krav til plastproduktion. To af initiativerne $(6,8)$ handler om interventioner i affaldssortering $\mathrm{i}$ form af et nyt pant- og retursystem og indførslen af nye standarder for indsamling og sortering af plastaffald. To af initiativerne $(11,27)$ har fokus på hav og strande. Endeligt handler et af initiativerne om øget producentansvar (7). Der er som sagt 27 initiativer, men kun 50 millioner kroner. Der er bemærkelsesværdigt få håndfaste krav til virksomhederne.

Plasthandlingsplanen bliver da heller ikke modtaget positivt af organisationer som Plastic Change, Danmarks Naturfredningsforening og Det Økologiske Råd. I en pressemeddelelse fra Plastic Change fra den 14. december 2018 fremgår det, at handlingsplanen kun får syv glade smileys ud af 43 mulige. Planen er ifølge disse organisationer slet ikke ambitiøs nok (Plastic Change, 2018). I pressemeddelelsen fremgår det, at disse tre miljøorganisationer var kommet med 43 forslag til, hvad en plasthandlingsplan bør indeholde. Kun syv af de i alt 43 forslag er blevet som foreslået. Der fremsættes ikke blot en moderat kritik af, at der ikke er afsat nok midler. Der er faktisk "... slet ikke afsat tilstrækkeligt midler, og der mangler mål for de forskellige indsatser; for eksempel hvornår den ensartede plastsortering i kommunerne skal være implementeret” (Plastic Change, 2018). Der er ellers tale om forslag, som plastindustriens brancheforening i høj grad bakker op om. I et fælles indlæg publiceret den 23. oktober 2018 (Plastindustrien, 2018c) fremgår det, at de tre miljøorganisationer sammen med Plastindustrien er enige om en række forslag, som omfatter to hovedelementer.

- Initiativer til bedre sortering af plastaffaldet i husholdningerne og det offentlige rum. Her peges på nødvendigheden af, at der kommer ensartet sortering i kommunerne, så der kommer ens affaldsfraktioner. Det påpeger nødvendigheden af fælles nationale rammer for plastsortering (Plastindustrien, 2018d). 
- Dernæst skal der skabes klare rammer for produktionen af plast, så at den plast, vi bruger i dag, lettere kan indgå i en cirkulær økonomi. I den forbindelse henvises til et katalog udarbejdet af Forum for Plastemballage, som er udarbejdet af Plast.dk, NGO'er, detailhandel, politikere og viden-personer (Plastindustrien, 2018e).

Det fremsættes ligeledes, at den danske plaststrategi skal være i tråd med EU's plaststrategi, men den må gerne være mere ambitiøs. Overordnet set endte planen med at være noget mindre ambitiøs end, hvad de forskellige foreninger havde håbet på. Skuffelsen er specielt begrundet i de meget få midler, som er afsat til formålet (50 millioner) og manglen på konkrete bindende målsætninger omkring både plastsortering og design til genanvendelse. En del af initiativerne omhandler forskning og videns-indsamling, som til og med skal udføres med meget få midler. Erfaringsmæssigt kan det vare mange år, før sådanne initiativer for alvor slår igennem. Andre initiativer er hensigtserklæringer, som der først skal forhandles om.

I forhold til at skabe betingelserne for at flere bæredygtige forretningsmodeller kan opstå eller/vokse, så er beskeden klar fra regeringen side, når de siger, at frivillighed skal være det bærende princip. Det betyder reelt, at der er forholdsvis lidt hjælp at hente fra regeringen. Regeringen anbefaler, informerer om problemstillingen, henstiller til samarbejde og støtter forskning (med få midler). Initiativet overlades til entreprenører, private virksomheder, NGO'er, brancheforeninger, kommuner og frivillige foreninger. De virksomheder, som vi har besøgt inden for genanvendelsesområdet, er alle sammen fornuftige virksomheder, som forsøger at gøre noget godt for samfundet samtidig med, at de bygger en forretning op. De specialiserer sig og tager de plastfraktioner, som kan bidrage til en rentabel forretning. En overordnet vurdering er, at regeringens handlingsplan kun i begrænset omfang flytter grænsen for, hvornår plastaffaldsfraktioner er rentable til fordel for de entreprenører og andre virksomheder inden for plastgenanvendelsesområdet, som EU og regeringen ellers eftersøger.

\section{G. Alternative løsningsmodeller: Offentligt lederskab og innovation}

Regeringens plasthandlingsplan mangler altså ambitioner. Med begrebet frivillighed frem for regulering kan vi sige, at nødvendige løsninger må komme et andet sted fra, det være sig fra lokale samarbejder i regioner og kommuner. Ren Kystlinje kan ses som et resultat af sådanne samarbejder, hvor vi også nåede et pænt skridt videre i forhold til at dele viden og innovere i forhold til rydning af strande og i forhold til at forstå problemstillingen om genanvendelse af havplast og plast generelt set. Spørgsmålet er, hvor meget kraft der vil ligge bag sådanne samarbejder. Det afhænger af omstændighederne og viljen hos de lokale aktører. Der er imidlertid innovationsmodeller, som kan bidrage til alternative løsningsforslag, og som har den fordel, at de potentielt kan skabe en bredere 
ansvarsbevidsthed hos kommuner, virksomheder, organisationer, foreninger og civile. Disse modeller kan også systematiseres og bruges som udgangspunkt for regional eller kommunal udvikling. Her har kommunerne et stort ansvar for at sætte sådanne tiltag i værk. Kommunerne har ansvaret for den lokale udvikling og erhvervspolitik, ligesom de i mange tilfælde er nogle af de største arbejdsgivere. Derfor kan kommunerne påtage sig det ansvar at forsøge at tackle plastudfordringen og andre bæredygtighedsudfordringer ved at aktivere lokale ressourcer i fælles aktiviteter og projekter.

Sådanne kan have form af offentlig-private samarbejder, hvor aktører uden for kommunerne og andre offentlige organisationer, inviteres indenfor til at bidrage med løsninger på samfundsmæssige problemer. En fordel ved dette er, at plastområdet er det, som Christian Bason kalder et "wicked problem" (2018) for samfundet. Et "wicked problem" er et komplekst problem, som kan forstås og fortolkes på mange forskellige måder og fra mange forskellige synsvinkler, og hvor der er interessenter med forskellige konfliktende mål. Wicked problems kræver samarbejder og samskabelse på tværs, fordi offentlige organisationer i mange tilfælde simpelthen ikke har kompetencerne til at løse problemerne in-house. Men en anden fordel er også den simple, at forskellige aktører i samfundet ansvarliggøres, og dermed får både større bevidsthed og ejerskab til problemstillingen.

Offentlige-private innovationsforløb (Abildgaard, 2017) er i denne sammenhæng nye samarbejdsformer, hvor offentlige og private aktører går sammen i udviklingen af nye produkter eller processer. Disse samarbejder er mere vidtgående end traditionelle samarbejder, som har fokuseret på indkøb. Abildgaards undersøgelse viser dog også, at sådanne samarbejder kan være vanskeligt at få til at fungere. Måske kan der på plastområdet tilvejebringes en tilpas fælles problemforståelse og fortælling, som kan skabe betingelserne for en fælles fortælling, der kan samle forskellige interessenter og skabe mere helhedsorienterede løsninger på plastområdet.

Sådanne typer af samarbejde kan sagtens udvides til også at indbefatte det, som bliver kaldt den tredje sektor (Bason, 2018, Mintzberg, 2015). Den tredje sektor dækker den myriade af private foreninger, som eksisterer i samfundet, og som udgør en potentielt kraftfuld samarbejdspartner, fordi de netop er organiseret $\mathrm{i}$ forvejen. Plasticforbrug og håndtering i idrætsforeninger og foreninger, som står for større kulturelle arrangementer, er oplagte aktører. Sådanne civile aktører deltog faktisk også i Ren Kystlinje i forhold til rengøring af kyster og strande. Endelig kan sådanne samarbejder også udvides til at inkludere uddannelse og uddannelsesinstitutioner, så der faktisk er fire sektorer involveret: offentlige organisationer, private virksomheder, foreninger og civile aktører samt uddannelsesinstitutioner. 
Det er svært at gisne om, hvor meget potentiale, der ligger i sådanne lokale samarbejder. Det afhænger af, hvilke ressourcer der er i de lokale områder, og hvordan kulturen og traditionerne skaber grundlag for lokalt samarbejde. Historisk har man måske overset de potentialer, der ligger heri. Et populært begreb, som er opstået inden for økonomi er the "commons", som er en tredje ejerskabsform, hvor grupper af frivillige og borgere får ansvaret for at administrere bestemte områder (Bollier, 2007; Ostrom, 1990; Ostrom \& Chang, 2012). Elinor Ostrom fik nobelprisen for netop at påvise værdien af denne ejerskabsform, som er baseret på samarbejde, frivillig arbejdskraft og fællesskab. Aktører kan igennem den simple teknologi "at tale sammen" (Harvey, 2012) undgå det, som er blevet kaldt "the tragedy of the commons" (Hardin, 1968), som på vanlig rationel vis påviser, at the commons vil gå til grunde, fordi de enkelte medlemmer vil begynde at forfølge egeninteresser. Det "at tale sammen" på tværs af virksomheder, offentlige organisationer og foreninger samt andre aktører har altid været en central tanke i den danske samarbejdsmodel. Denne model kan og bør være et af hovedelementerne i en plasthåndteringsstrategi og kan udvides til deciderede strategiske samarbejder, som er lig dem, der er skitseret ovenfor.

Det er måske sådanne organiseringsmodeller, som kan være nogle af kernepunkterne i en skandinavisk ledelsesmodel for at løse samfundsmæssige problemer. Kommunerne har andre muligheder for at påvirke viljen til samarbejde. Et element i en kommunal CSR-strategi er eksempelvis at fokusere på at stille krav til leverandører af varer og tjenesteydelser til det offentlige. Indkøbsmusklen i forhold til krav om anvendelse af genbrugsplast, krav om design af plast og til plasthåndteringen kan anvendes progressivt og lokalt her.

\section{H. Konklusion}

Plastaffald udgør et komplekst politisk problemområde, som vi må anskue ud fra et holistisk perspektiv. Artiklen har diskuteret plastaffaldshåndtering i Danmark og mere specifikt, hvis og hvordan CØ kan realiseres i Danmark. Det er blevet anskueliggjort, hvordan Delt Værdi er en dominerende tanke, som EU's plastcirkulære er baseret på. Denne artikel har tydeliggjort begrænsningerne ved Delt Værdi og CØ, samt problematiseret EU's plastcirkulære og den danske plasthandlingsplan. I den sidste del har vi skitseret nogle mulige ledelses- og samarbejdsmodeller, som kan tages i anvendelse i forhold til at gøre CØ mere realiserbart. Modsat Delt Værdi, som implicit argumenterer for, at entreprenører og virksomheder skal påtage sig opgaven, bygger disse ledelsesmodeller på et fælles ansvar. Det er mobiliseringen af et fælles ansvar, som er centralt i disse ledelsesmodeller, og som kan fungere som et alternativ til både regulering og blind tiltro til private virksomheders etiske omtanke. 


\section{Litteratur}

Abildgaard, A. (2017). Viljen til markedsgørelse: En dispositionel og diagnostisk beskrivelse af ureflekterede sandheder, subjektpositioner og mulig selvformation i offentlig-privat innovation. Aalborg: Aalborg Universitetsforlag. PhD afhandling. https://doi.org/10.5278/vbn.phd.hum.00076

Bason, C. (2018). Leading Public Sector Innovation: Co-creating for a Better Society. Bristol: Policy Press. https://doi.org/10.2307/j.ctt9qgnsd

Bollier, D. (2007). The growth of the commons paradigm. In C. Hess \& E. Ostrom (Eds.), Understanding Knowledge as a Commons: From Theory to Practice (pp. 27-40). Cambridge, MA: MIT Press.

DAKOFA. (2017). Nyhed: Ny analyse skaber overblik over al plast produceret - nogensinde.

Retrieved November 7, 2019, from Dansk Kompetencecenter for Affald og Ressourcer website: https://dakofa.dk/element/ny-analyse-skaber-overblik-over-al-plast-produceret-nogensinde/

Det Store Plastleksikon: Alt hvad du skal vide om plast. (2019). Retrieved November 7, 2019, from Plast.dk website: https://plast.dk/det-store-plastleksikon/

European Commission. (2018a). EUR-Lex-52018DC0028-EN - EUR-Lex. Retrieved November 7, 2019, from https://eur-lex.europa.eu/legal-

content/EN/TXT/?qid=1516265440535\&uri=COM:2018:28:FIN

European Commission. (2018b). European Commission-PRESS RELEASES - Press release-Plastic Waste: A European strategy to protect the planet, defend our citizens and empower our industries. Retrieved November 7, 2019, from https://europa.eu/rapid/press-release_IP-18-5_en.htm

Freeman, E. R., Wicks, A. C., \& Parmar, B. (2004). Stakeholder Theory and "The Corporate Objective Revisited." Organization Science, 15(3), 364-369. Retrieved from https://www.jstor.org/stable/30034739 https://doi.org/10.1287/orsc.1040.0066

Friedman. (1970). The Social Responsibility of Business Is to Increase Its Profits. New York: New York Times.

Garriga, E., \& Melé, D. (2004). Corporate Social Responsibility Theories: Mapping the Territory. Journal of Business Ethics, 53(1), 51-71. https://doi.org/10.1023/B:BUSI.0000039399.90587.34 
Hardin, G. (1968). The Tragedy of the Commons. Science, 162(3859), 1243-1248.

https://doi.org/10.1126/science.162.3859.1243

Harvey, D. (2012). Rebel Cities: From the Right to the City to the Urban Revolution. London. Verso Books.

Jyllands-Posten. (2018). FN: »Hvis udviklingen fortsatter, vil der i 2050 vare mere plastik end fisk $i$ verdenshavene«. Retrieved November 7, 2019, from https://jyllands-

posten.dk/international/ECE10662135/verdens-miljoedag-i-new-delhi-markeres-rapport-fra-fn-omplastforurening/

Miljø- og Fødevareministeriet. (2018). Plastik uden spild-Regeringens Plastikhandlingsplan. Miljøog Fødevareministeriet.

Mintzberg, H. (2015). Rebalancing Society: Radical Renewal Beyond Left, Right, and Center. Oakland, CA: Berrett-Koehler Publishers. https://doi.org/10.3917/rimhe.024.0067

Ostrom, E. (1990). Governing the Commons: The Evolution of Institutions for Collective Action. Cambridge, UK: Cambridge University Press. https://doi.org/10.1007/978-3-531-90400-9_93

Ostrom, E., \& Chang, C. (2012). Future of the Commons: Beyond Market Failure and Government Regulations. London: Institute of Economic Affairs.

Out to Sea - an ocean of plastic. (2019). Retrieved November 7, 2019, from Tekniska Museet website: https://www.tekniskamuseet.se/en/discover/exhibitions/out-to-sea-an-ocean-of-plastic/

Plastic Change. (2018). Få smileys til plasthandlingsplan. Retrieved November 18, 2019, from Plastic Change website: https://plasticchange.dk/knowledge-view/smileys-til-plasthandlingsplan/

Plastindustrien. (2018a). Plastindustrien roser forslag om at ensrette plastindsamling $i$ kommunerne. Retrieved November 7, 2019, from Plast.dk website:

https://plast.dk/2018/12/plastindustrien-roser-forslag-om-at-ensrette-plastindsamling-ikommunerne/

Plastindustrien. (2018b). Vi vil designe plastemballage til genbrug og genanvendelse. Retrieved November 7, 2019, from Plast.dk website: https://plast.dk/vi-vil-designe-plastemballage-tilgenbrug-og-genavendelse/ 
Plastindustrien. (2018c). Foelles ønsker fra NGO'er og Plastindustrien til plasthandlingsplanen. Retrieved November 18, 2019, from Plast.dk website: https://plast.dk/2018/10/debat-faellesoensker-til-plasthandlingsplanen/

Plastindustrien. (2018d). Forum for cirkuloer plastemballage: Resultater og anbefalinger. Retrieved November 18, 2019, from Plast.dk website: https://plast.dk/tema/forum-for-cirkulaerplastemballage/

Plastindustrien. (2018e). Vi vil øge kvaliteten i genanvendelsen af plastemballage fra husholdninger. Retrieved November 18, 2019, from Plast.dk website: https://plast.dk/vi-vil-oegekvaliteten-i-genanvendelsen-af-plastemballage-fra-husholdninger/

Porter, M. E., \& Kramer, M. R. (2011). Creating Shared Value. Harvard Business Review, 89, 62-77. Retrieved from https://www.hbs.edu/faculty/Pages/item.aspx?num=39071

Ren Kustlinje-Symbioscentrum (2018). Retrieved November 7, 2019, from http://www.symbioscentrum.se/projekt/avslutadeprojekt/renkustlinje.4.4835a2a0164870f216771 $\underline{02 . h t m l}$

Vallentin, S. (2011). Afkastet og anstændigheden. Frederiksberg: Samfundslitteratur.

Video-Affald.dk. (2019). Retrieved November 7, 2019, from

https://www.affald.dk/da/ungdomsuddannelser/plast/video.html 